\title{
Food and Water Consumption Sequence Number
}

National Cancer Institute

\section{Source}

National Cancer Institute. Food and Water Consumption Sequence Number. NCI

Thesaurus. Code C119837.

An identifier that describes the relative position of food and water consumption data within a series. 